\title{
Resiliency, Professionalization and Identity. a Study in Relation to Achievement at University at the Light of a New Paradigm: the Spiral of Three Dimensional of Sens ${ }^{1}$
}

\author{
Dr. Miriam Aparicio \\ National Council of Scientific Research (CONICET), Universidad Nacional de Cuyo \\ (Cuyo National University). Mendoza. Argentina miriamapar@yahoo.com
}

\begin{abstract}
This study is part of the broad research program on University Quality Assessment. It falls into the Sub Program of Quality Education Optimization in relation to students' achievements, with a view to implementing teachers' support and professionalization mechanisms. The aim was to go deep into the causes for delay in finishing studies in our country, as well as to become aware of the strong "reasons" leading to a delay, globally, of over the half of the pre-established time assigned to different courses of studies. The country policies combine with institutional "decisions" and the situation of the primary actors, that is, delaying students. There are three levels: macro national, meso institutional and micro, or the one concerning the individuals who, within the still "disciplinary" programs, often disregard the formation and/or consolidation of social competences that make an impact on individuals' achievement and therefore, on the quality of the universities. Here we stop to analyze the results related to the Resiliency factor (quantitative level). It should be noticed that the model included factors of different types (basic, personal, occupational, structural, pedagogical, institutional and psychosocial ones), taking a long period (more than 20 years of the National University of Cuyo and 6 Faculties). The results show that Resiliency is one of the factors with higher impact on the university achievement (bivariate and multivariate level). We used the Henderson and Milstein's method, which shows degrees of resiliency at the personal, institutional and teachers' levels, evidencing where the strengths and weaknesses are located. There appear different identities related to different Faculties and Courses of Study; identities linked to the students' performance. The findings are relevant within the context of a high level of failure in our universities, which could decrease if we implemented programs aimed at strengthening those aspects that "develop" out of the system (we are not born with them) and helping Professionalization through the creation of different mechanisms. That would have an impact on personal achievement and it would ultimately improve the Quality of the Educational System in the country.
\end{abstract}

Keys words: University, Performance, Identities, Professionalization, Resiliency, New Approach

\section{Introduction}

This work deals with the general issue of Institutional Quality (in this case, University), and it participates in an institutional contest, with the view of continuous improvement (Aparicio 2006 a and b; 2008 a, 2009 a, c and f, 2012 b, 2014 a, b and c, 2015 b, c, d). It was carried out considering a population of individuals who prolong their studies. This represents a widespread problem evident by the lack of figures on delay in studies and dropout of university.

This work will contribute to thoroughly determine the reality at university and the sub-factors underlying the high levels of failure. Only $11 \%$ of the students globally obtain their degree; $60 \%$ drop out their studies, and the rest "will decide" to extend them. This problem represents a material and human cost in terms of frustration. Among the psychosocial answers there appeared anonymous answers, blanks, depression or activism, etc. The characteristics of university education, based especially on the disciplinary aspect, could be one of the factors present at the baseline of other competences (social and procedural, which concern to the "know-how and know how to be" level in a professional scenario) such as communicational competences, coping strategies, resilience, etc. As regards resilience, core topic of this paper, it develops social bonds and relational competences which will be useful within the university, the labor world and life itself.

\footnotetext{
1 Topic: Barriers to Learning (age, psychosocial factors, ethnicity. . .) - Researches on psychology of education, social, health, organizational studies - Others: A New Paradigm.
} 
Resilience may be defined as the individual's capacity to react to and endure the adversities due to an adaptation process and in spite of the risks and such adversities themselves. As we see it, all these elements are essential as regards success and failure. We will not deal with the theory; on the contrary, we should clearly state that the capacity to resist pressure and lead a healthy life within an unhealthy environment implies social and intrapsychic processes in which institutions and primary socializing instances play a fundamental role (Hernández, 1998; Puerta de Klinkert, 2002) Resilience is, then, a personal and institutional construction; is not inborn: it is shaped within a context. That is why, it was included in our theoretical model and analyzed from our sui generis systemic approach: Le Spiral Three Dimensional of Sens (Aparicio, $2015 \mathrm{~d}$ ). It is the context in which the individual is inserted the factors that enhances or disperses the chances to overcome obstacles. In view of the "relative" failure of students who are delayed in their studies, two questions arise: Does a weak level resilience influence? Does the university community with its dominant system of beliefs and values influence on the possibilities of being successful? Without knowing the situation based on empirical information, it should be quite difficult to cause changes at the level of intervention.

General Objective: Determining the factors (core, psychosocial, structural, pedagogical and institutional) associated to success at university.

Specific Objectives: a) Determining the sociocultural and psychosocial which significantly influence on delay in studies. b) Identifying the population at risk. c) Provide elements to the authorities of each Faculty in order to implement changes contributing to goal achievement (changes on syllabuses, curriculums which are more adapted to the demands of the labor market, revision of promotion and evaluation systems, etc. ). d) Determining, at the qualitative level, the profound reasons underlying delay.

General Hypothesis: psychosocial factors - such as motivation, attributional style, coping, and resilience - favored by socialization (family, peers, school, etc. ) and by the training stages (school, university) internalized by the individuals. Such factors could associate to profiles of higher university and professional achievement.

Specific Hypotheses: Higher degrees of resilience (RESIL) have a positive impact on University achievement (UP) and on the chances of labor insertion.

\section{Methodology}

We used the quantitative and qualitative methodology.

The sample consisted on 229 individuals at six Faculties: Philosophy and Literature (Educational Sciences), Economical Sciences (Accounting and Management), Political Sciences (Social Communication), Law, Medicine and Engineering (Civil, Industrial and Petroleum Engineering) at Cuyo National University (1985 - 2004), who were interviewed at home. These individuals have enrolled at university since 1985 and reenrolled in 2004 but they are not attending courses; they are ghost students. Out of 1880 identified individuals according to institutional listings, the actual number of interviewed students (which we were able to locate) was $\mathrm{N}=229$.

As regards techniques, we have used a semi-structured interview and specific test to measure the different psychosocial variables related to achievement (UP): Strategies to "overcome" difficulties (Frydenberg \& Lewis, 1996), attributional styles (Seligman, 1991), motivational factors (Montero \& Alonso Tapia, 1992) and Resilience (Henderson \& Milstein, 2003). In this work, we deal with the importance of Resilience in order to overcome difficulties within university institutions.

As regards Resilience, the Henderson and Milstein's questionnaire consists of 3 scales: Student (RESIALUM), Staff administration and teachers (RESIPERS), and Institutional (RESIFACU); and its 6 sub-scales which can be regrouped in 2 sub-dimensions. The aspects to be evaluated are: I. Reducing the risk: 1 . Enhancing the pro-social bonds; 2 . Defining clear and firm limits (Creating and implementing coherent school policies and procedures and explaining expectations in terms of behavior. Stating written rules and transmitting them clearly); 3. Teaching competences for life (cooperation, conflict solving, communicational competences, problem solving skills, healthy stress management). II. Constructing Resilience: 1. Providing affection and support; 2. Defining and transmitting high and realistic expectations (avoiding the notion of development plafond); 3. Providing possibilities of significant participation (granting students and the institutional authorities the possibility of making decisions and, especially, of fixing goals with the help of others). 
As regards University Achievement (UP), in a broad sense, it comprises the following categories: a) Achievement: finishing studies (obtaining the degree); b) Delay: finishing studies in a longer period of time than the officially pre-determined one; c) Failure: dropout.

Performance, strictly speaking, was understood considering the following indicators (UNCuyo Statistics Department):

-Number of years studying. (2005 - Cohort)

-Number of years for the course of studies (ANPLAN)

-Subjects failed (MATPLAN-REUSSI)

-Total number of subjects in the curriculum (MATPLAN)

-Number of failures (APLAZOS)

-Passed subjects (MATPLAN)

$\left.U P=\left\{\frac{1}{\left\{\left[\frac{(2005-C O H O R T)}{\text { ANIPLAN }}\right]+\left[\frac{\text { MATNOAPR }}{\text { MATPLAN }}\right]+\left[\frac{N^{\circ} \text { Failures }}{\text { SubjectsFailed }}\right]\right.}\right\}\right\}$

\section{Results}

They show the role of Resilience in the Extension of Studies (UP).

The Resilience factor, as already stated, has been measured at 3 Scales: Student (RESIALUM), Staff - administration and teacher - (RESIPERS) e Institutional (RESIFACU). At the 3 Scales, the average is focused on category 3 , which indicates that Resilience training is at the "initial" stage. This means that, in general terms, in all Faculties, institutional evaluation, as a means of modeling Resilience in students, in the Staff and in the Institution as an organization, is quite low. On the other hand, each institution has its own profile, since some appear as Resilience breeders among students, staff and/or the institution itself (Aparicio, 2009a , Vol. 1).

There should be resilience source areas (see Faculties/Courses of Study I our research) favoring it, that is, instances causing/favoring: a) the creation of supporting social networks; b) the consolidation of a transcendental meaning of life; c) the development of skills to build solid, respectful and rewarding relationships, in order to obey rules and accept limits in a conscientious manner; d) the ability to solve problems through analysis and reflection; e) the development of self-esteem based on a realistic viewpoint of one's own potential and limitations.

Let us analyze the results showing the variables which have an influence on achievement.

Bivariate Analysis: regarding the factors for "obstacle overcoming" in our model - Resilience and Coping -, the results show that the most significant Resilience Scales are the Pro-social Bond (RESIVINC), clear limits (RESILI) and High Expectations (RESIEXPE). More precisely, when the Pro-social Bond increases, University Performance (UP) diminishes; on the contrary, when there are Clear Limits and High Expectations, the Ups increase.

We stress, then, the positive effect of expectations in relation to the learning of limits, something that we lack nowadays. On the opposite side lies the very high pro-social bond, which leads to studies dropout. At the level of demands, experience in different Faculties shows that as demands increase, so does performance (lower level of delay in studies). 
Multivariate Analysis: Let us focus for a moment on the University Achievement (UP) model and analyze which are the variables that can predict achievement. Among the Psychosocial Variables, Resilience is precisely the most influential. Two sub-scales are associates to UP: bonds and opportunities offered to the individuals. (RESIVINC and RESIOPOR). The former contributes negatively; that is, as the students are more devoted to social life, their achievement levels drop. The latter contributes positively. I other words, the more the possibilities for progress, the higher the UP.

RESIVINC: probability is lower than $5 \%(0.0328)$. Coefficient is -0.003520 , which reveals a negative relationship with UP. In other words, when these bonds are exaggerated and sociability is quite considerable, studying becomes less important and time extends.

RESIOPOR: probability is lower than $5 \%(0.00057)$, which indicates a higher association in the multivariate model than RESIVINC. Coefficient is 0.004104 ; that is, there exists a positive relationship with UP: when there are opportunities for development, academic performance improves and extension in studies decreases.

\section{Discussion}

These results show the need for developing resilience means and sources within the organizations. Resilience always leads to success for the individuals as well as for the organization they belong to (Aparicio, 2005, 2007a, 2007b).

On the other hand, the global findings show the significance of other core variables of achievement micro-theories (clear goals, realistic expectations, effort, coping, etc. ). Finally, there appears the influence of context: some Faculties generate and consolidate Resilience where there are others in which this "social competences" is weak.

Disciplinary and Institutional Identity/ldentities. This situation reveals that the University is in need of teachers' professionalization in order to favor competences development beyond the disciplinary area; on the part of the students, it demands the consolidation of goals, limits, stamina to overcome obstacles, expectations, which are presently quite diluted due to degree devaluation.

\section{Conclusion}

Understanding the influence of certain factors in the light of achievement explanatory theories could favor the development of individuals and institutions as well as the transformation of continuing education practices and mechanisms.

\section{References}

Aparicio, M. (2005). Les facteurs psychosociaux en relation avec la réussite universitaire et professionnelle. $2 \mathrm{e}$ thèse de doctorat. Paris: Université René Descartes, Sorbonne. Mention: Très honorable avec félicitations du jury a l'unanimité.

Aparicio, M. , 2006 a. Trayectorias universitarias. Un análisis a la luz de metodologías cuantitativas, ZETA, Mendoza.

Aparicio, M. , 2006 b. Trayectorias universitarias: Un análisis a la luz de metodologías cualitativas, ZETA, Mendoza.

Aparicio, M. (2007a). Les facteurs psychosociaux à la base de la réussite universitaire et professionnelle : aspects psychologiques et organisationnels. HDR en Psychologie. Lille : Université de Lille3. .

Aparicio, M. (2007b). Mobilité et réussite universitaires et professionnelles. Du niveau macro au niveau micro. HDR en Sciences de l'éducation. Paris : Université Paris X, Nanterre.

Aparicio, M. (1995 a). Educación Superior y Empleo. Propuesta de un modelo sistémico, Ph. D. Thesis, Universidad Católica Argentina Santa María de los Buenos Aires, Argentina.

Aparicio, M. (1995 b). Agenda-Setting. Un análisis desde sus supuestos e implicancias educacionales, Master Thesis in Education Social Communication and Human Relations, UCA, 2 Vol. 
Aparicio, M. (2006 a). Trayectorias universitarias. Un análisis a la luz de metodologías cuantitativas, ZETA, Mendoza.

Aparicio, M. (2006 b). Trayectorias universitarias: Un análisis a la luz de metodologías cualitativas, ZETA, Mendoza.

Aparicio, M. (2007 a). Les facteurs psychosociaux à la base de la réussite universitaire et professionnelle: aspects psychologiques et organisationnels, HDR (Psychologie), Lille, Université Lille 3.

Aparicio, M. (2007 b). Mobilité et réussite universitaires et professionnelles. Du niveau macro au niveau micro. HDR (Education), Université Paris X, Nanterre.

Aparicio, M. (2008 a). Causas de la Deserción en Universidades Nacionales, Ed. San Juan National University, San Juan.

Aparicio, M. et al. (2008 b). Social représentations of the teacher profession and the social construction on professional identities at the beginning of the teaching carrier. A french-argentinian study: IFM de Créteil (Francia) e Institutos de Formación Docente de Mendoza (Argentina). Ministerio de Educación, Cooperación bilateral franco-argentina.

Aparicio, M. (2009 a). La demora en los estudios universitarios. Causas desde una perspectiva cuantitativa, EDIUNC, Mendoza.

Aparicio, M. (2009 b). La demora en los estudios universitarios. Causas desde una perspectiva cualitativa, EDIUNC, Mendoza.

Aparicio, M. (2009 c). Les facteurs psychosociaux et la réussite universitaire et professionnelle, ANRT, Lille, Université de Lille 3.

Aparicio, M. (2009 f). Opening Conference, Congrès de l'Ecole de Gestion: Nouvelles carrières. Nouvelles compétences. Les trajectoires universitaires et professionnelles: entre formation et travail, Faculté des Sciences de la gestion, Université de Rouen, 13-14 May.

Aparicio, M. (2012 a). La deserción universitaria y su relación con factores psicosociales. Revista Dialogo, 20, 28-39.

Aparicio, M. (2012 c). Crise d'identité et devenir professionnel des étudiants qui sont engagés dans un doctorat en éducation/formation. Une approche comparative franco-argentine. Biennale internationale de l'éducation, la formation et des pratiques professionnelles, Cnam, Paris. July 4-6.

Aparicio, M. (2014 a). University Drop-Outs. A Systemic Play of Subjects, Institutions and Macro Contexts, Journal of Educational and Social Research, 4, 2, Special Issue - April. ISSN 2240-0524.

Aparicio, M. (2014 c). Postgraduate Level and its Impact on Academic Studies and Professional Careers, Social and Job Mobility and Identity. A Study about PhD Graduates and PhD Students at UNCuyo, in the Light of a sui generis Paradigm, Journal of Educational and Social Research, 4, 2, Special Issue - April.

Aparicio, M. (2015 b). Identity, Weakening and Professionalization: A Study of Graduate and Postgraduate Students (19872002) in the Light of the Three-Dimensional Spiral of Sense Theory. In International Handbook of Professional Identities, A. M. Costa e Silva \& M. Aparicio (Ed. ). USA: Scientific \& Academic Publishing, 121-156. ISBN 978-1-938681-35-6.

Aparicio, M. (2015 c). Towards a sui generis systemic theory: The Three-Dimensional Spiral of Sense. A Study in Argentina Applied to Identity and Professionalization (Article 1). Asian Academic Research Journal of Social Sciences \& Humanities (AARJSH) [ISSN $2278-859$ X].

Aparicio, M. (2015 d). The Theory of the Three-Dimensional Spiral of Sense: An Application with special Reference to Identity and Professionalization in other Disciplinary Areas (Article 2). Asian Academic Research Journal of Social Sciences \& Humanities (AARJSH) [ISSN 2278 - 859X]. 
Frydenberg, E. \& Lewis, R. (1996). ACS. Escalas de Afrontamiento para Adolescentes. Adaptation J. Pereña \& N. Seisdedos. Madrid: TEA.

Henderson, N. \& Milstein, M. (2003). Resiliencia en la escuela. Buenos Aires: Paidós.

Montero, I. \& Alonso Tapia, J. (1992). Cuestionario Mape II. In J. Alonso Tapia. Motivación en la adolescencia. Madrid : UAM.

Puerta de Klinkert, M. P. (2002). Resiliencia. La estimulación del niño para enfrentar desafíos. Buenos Aires: Lumen.

Seligman, M. (1991). El optimismo es una ventaja y un placer que se adquiere. Buenos Aires: Atlántida. 